\title{
The Effects of the Intestate Succession Law 1985 (PNDCL 111) and the Head of Family Accountability Law 1985 (PNDCL 114) on Youth Access to Agricultural Land in the Techiman Traditional Area of Ghana
}

\author{
Joseph Kwaku Kidido \\ Department of Land Economy, College of Art and Built \\ Environment, KNUST, Kumasi, Ghana \\ jkidido@yahoo.co.uk; jkkidido.cap@knust.edu.gh \\ John Tiah Bugri \\ Department of Land Economy, College of Art and Built \\ Environment, KNUST, Kumasi, Ghana \\ jtbugri@yahoo.com \\ and
}

\section{Raphael Kasim Kasanga}

Centre for Land Studies, College of Art and Built Environment, KNUST, Kumasi, Ghana raphaelkasim@yahoo.co.uk

DOI//http://dx.doi.org/10.4314/gjds.v15i2.2

\begin{abstract}
This paper examines the effects of the Intestate Succession Law 1985 (PNDCL 111) and the Head of Family Accountability Law 1985 (PNDCL 114) on youth access to agricultural land in the context of customary land tenure. Using the Techiman Traditional Area in Ghana as a case study, the study sampled 455 youth and 23 elders using multiple sampling techniques. It was revealed that while PNDCL 111 has had some positive effects on the ability of the youth to inherit personal properties of their deceased parents; its exemption of family land in terms of application takes agricultural land access through inheritance outside the purview of the law. Given that majority of agricultural lands are family property, youth land access option through inheritance under the law is thus limited. Again, there are no more vacant lands to be acquired as personal property which the youth can inherit under the law. In the case of PNDCL 114, the study found that the law provides
\end{abstract}


no practical support to the youth in asserting claims to land or seeking accountability from their elders over land proceeds. It is recommended that both PNDCL 111 and PNDCL 114 be reviewed to reflect these limitations. Also, the Head of Family Accountability law should make Alternative Dispute Resolution (ADR) mechanisms an integral part of the law to improve on dispute adjudication given that court actions to demand accountability are not generally culturally acceptable.

KEY WORDS: Legislative interventions, Youth, Land, Access, Ghana

\section{Introduction}

The youth constitute the true wealth and future of Ghana (MYS, 2010). Addressing their economic aspirations and hopes must be an integral part of the development agenda of the country. They require attention and support against tendencies which could thwart their struggle for economic survival. Underestimation of the needs and concerns of the youth could prove too costly for the society to bear. This is because, youth agitations can destabilise society, create insecurity and their youthful exuberance could be exploited to perpetuate violence by unscrupulous individuals and politicians. Youth as an intermediate social category can use their leverage to trigger off a process of change in a wider political setup (Sharp, 2002). The Arab Spring in 2011, reiterates the threat posed by huge numbers of unemployed and impoverished youth to the political order (Lintelo, 2011). The front role involvement of youth in world's street protests in recent years is borne out of their disillusion in institutions' failure to tackle their employment needs and the disproportionate impact unleashed on the youth by economic downturns (Annan, 2013).

According to the World Bank (2007), failure to channel youth into productive pursuit could prove too costly for the society. In view of this, it is imperative for governments, donor agencies and civil society organisations to pay attention to youth issues and develop strategies to provide decent and productive work for them. There is therefore the need for policy makers in Sub-Saharan Africa to prioritise youth issues in the light of the Arab Spring (World Bank, 2014). Developmental policies should at least address the needs and aspirations of the youth (Lintelo, 2011).

It is noted that, the agricultural sector has immense employment potentials in developing countries (White, 2011) and will remain the world's single biggest source of employment (IFAD, 2010). The growing food demand and increasing demand for agricultural raw materials and energy for industries make the agricultural sector a viable venture now and in the future (World Bank, 2014). The sector thus 
offers the youth with vast employment opportunities in the face of tightening employment prospects in other sectors such as manufacturing, commerce and tourism occasioned by slow economic growth and lack of skills. As noted by Brooks et al. (2013), the agricultural sector already employs more of the youth in many rural areas in Africa. According to the World Bank (2014), expanding young people's opportunities in the agricultural sector in the rural areas is a significant catalyst for Africa to reap its demographic dividend. However, youth access to land is crucial to enabling them to harness the employment prospects in the agricultural sector. Their access to land under the customary land tenure system in some customary areas in Ghana is fraught with numerous challenges. For instance, Kidido et al. (2017) study in the Techiman area of Ghana revealed that, the youth were only able to access small and unviable land parcels for agricultural purpose and the holding terms were largely on temporary basis. They noted that elders were unwilling to release enough land to the youth but rather preferred to allocate land to wealthy adult farmers and property developers in the peri-urban areas thus creating artificial land shortage for their youth besides the general land scarcity. As a result, the customary mode of accessing land such as gift and inheritance were limited for the youth. High rental and acquisition cost of land driven largely by growing demand also undermined the youth's ability to access land through the land market mechanisms such as rental and purchase due to lack of resources (see Kidido et al., 2017 for detail analysis of these challenges).

Youth thus require outside support to build up economic independence especially from the agricultural sector. Abbink (2005) described this outside support as interventionist response that requires that remedial measures are developed and implemented to enable young people attain independent employment and social status, and civil representation. One clear case of the interventionist response espoused by Abbink is a legislative environment that supports and promotes youth access to land for agricultural purpose or benefit from land investments. Access to land is affected by many factors including the prevailing customary tenure system (FAO, 2002) as well as the legislative framework. This study focuses on the legislative dimension to understand how youth access to agricultural land is affected by the legislative framework in the country. There are many legislations regulating the use of land in Ghana. In fact, there are about ninety(9o) different pieces of legislations attached to the Ghana Land Policy document which are currently in enforce and affecting land in Ghana (GoG, 1999).

However, this paper examines the effects of two legislative interventions on access to agricultural land by the youth in the customary land tenure regime in the study area. These are the Intestate Succession Law 1985 (PNDCL 111) and The 
Head of Family Accountability Law 1985 (PNDCL 114) which relate to property succession and landholding accountability respectively given the potential relevance to land access at the family level where most agricultural land emanates. The PNDCL 111 intervenes in the succession of personal property of a person who dies intestate. The law does not affect family land, a dominant form of corporate tenure landholding arrangement under the customary tenure system in stool land areas of Ghana. It is thus imperative to examine how the non-application of this legislation to succession of family land impedes youth access to agricultural land. In the case of PNDCL 114, it essentially seeks to facilitate accountability over family property including land. It is also important to examine the extent to which the operation of this legislation supports youth access to family land and their ability to benefit from family land proceeds and investments. A legislative environment that facilitates youth access to land has the potential to help attract the youth into the agricultural sector, especially at the production level and this could help them fully exploit employment potentials in the sector.

\section{Brief Overview of Customary Land Tenure System in Ghana}

Customary land tenure has been defined as the "right to use or dispose of use-rights over land which rest neither on the exercise of brute force nor on the evidence of right guaranteed by government statutes but on the fact that those rights are recognised as legitimate by the community, rules governing the acquisition and transmission of these rights being usually explicit and generally known though not normally recorded in writing" (Fisher 1993, cf. Mends, 2006:9). It is a landholding arrangement in accordance with customary law (World Bank, 2010; Arko-Adjei, 2006; Mends, 2006). The term "customary land" refers to all categories of interests and rights held under the traditional systems and controlled by a chief, head of a clan or family (AUC-ECA-AfDB Consortium, 2011: 22). Customary land tenure arises from the 'accepted practices and traditions of traditional society in obtaining, using, distributing and disseminating of its land' (Mends, 2006).

From the above, it is clear that customary tenure system reflects on the ground rules of the local communities. Thus, customary law provides legitimacy and framework for the existence of customary land tenure. According to Cotula (2007), customary law is a body of rules (usually unwritten) founding its legitimacy in "tradition". It is essentially unwritten rules, norms and tenets created through usages and practices of a community over time. The 1992 Constitution of Ghana under the Article 11(3) noted "customary law" as "the rules of law which by custom are applicable to particular communities in Ghana" (GoG, 1992). The content 
of customary law is diverse and varies from village to village and its internal consistency also varies (Cotula, 2007). Cotula attributes the diversity to the cultural, ecological, social, economic and political factors and cautioned against generalisation of customary law because of its diversity. Customary law varies from one social field or organisation to another and what is applicable to one community as its customary law might differ from another community of just a few kilometres away. This diversity is reflected in the customary land tenure regime whose legitimacy and existence hinge on the customary law. Customary land tenure system is thus diverse with many variations across the country.

The customary tenure system constitutes a central pillar in land rights access especially in Africa and in the specific case of Ghana, majority of the land areas are controlled by customary institutions. In Ghana, customary institutions own about $78 \%$ of the land and of the remaining, $20 \%$ is under state control while $2 \%$ is held in dual ownership between the state and customary authorities (Larbi, 2008; Bugri, 2013). Deininger (2003) noted that customary institutions administer almost all of Africa's land area with immense institutional presence and trust by the locals. In the view of Mifsuf (1967) cited in Kasanga (1988: 3) "customary tenure is not just a type of land holding but also poses a wider implication for the 'social system, way of life, and beliefs of the people". Land under the customary system has both physical and spiritual significance. "Land is valued not for itself alone, its possession is a form of security, a symbol of prestige, and a source of power" (Gadalla, 1970). Mends (2006) noted that in some African countries and especially among the Akan tribe of Ghana, the customary land tenure system is woven into the very fabric of the traditional society. The concept of kinship, the family system and social relationship are influenced by land relations. According to Gildea (1964: 102) kinship, reverence for the ancestors and the belief in the spiritual power of the 'Earth' have given land tenure in Ashanti a peculiar feature. There is a belief that land is an ancestral trust offered to the living generation for their benefits and the benefits of the succeeding generations (Mends, 2006).

In many parts of Ghana, customary land tenure views land as a spiritual entity and a divine heritage which the spirits of the departed ancestors expect to be kept and passed onto the next generation (Asiama, 2008; Agbosu, 2000). Land under customary tenure is deemed to belong to "a vast family of which many are dead, a few are living, and countless members are unborn..." (Ollennu, 1962:2). Boni's (2008; 2006) research in the Sefwi area of Ghana affirms the ancestralisation of land rights. She notes that peoples' claim to land are linked to deeds of their ancestors in the past as well as their membership of the community which entitle them rights of participation and access as against non-members who are called 
'strangers'. Gildea also opined that, "If one asks a farmer how he came to secure the right to farm where he does, he will relate that he established his right by tracing his descent in the matrilineal line to an ancestor known to have farmed there before him." (Gildea, 1964: 102). Berry (2009a; 2009b) echoes similar narratives in her studies in both south western Ghana and Cote d'voire where land claims and entitlements under the customary systems are traced to ancestral lineages giving rise to differentiation of 'citizens' and 'strangers' in land relations.

There is, however, external intervention by the state in the customary land tenure arrangements occasioned by the operation of a pluralistic legal regime in Ghana. In the context of youth access to land, how do external statutory interventions by the state facilitate their land access? This paper seeks to address this question with the view to improving on access to land by the youth for agricultural purposes.

\section{Conceptual Framework of the Study}

Law is an important social construct which defines social relations. Law can be used to strengthen or correct certain social injustices causing marginalisation of certain class of people in a society (Kameri-Mote, 2005). Law is a social phenomenon reflecting all the essential varieties of social solidarity (Dupret, n.d). It is understood broadly as cognitive and normative orders generated and maintained in a social field such as a village, ethnic community, an association or state (Meinzen-Dick and Pradhan 2002). Law may simply be considered as any set of observed social norms (Woodman n.d: 4) and "covers a continuum which runs from the form of state law through to the vaguest forms of informal social control" (Woodman, 1998: 45). Griffiths however limited law to only state laws or formally enacted laws. According to Griffiths, "law is and should be the law of the state, uniform for all persons, exclusive of all other law, and administered by a single set of state institutions" (Griffiths 1986: 3). For the purposes of this paper, law is understood to refer to both formal rules enacted by the state and the informal customary norms and conventions which govern human behaviour and relationships to land in line with Woodman's definition.

Many laws thus exist and operate side by side and at times overlap and their combined impact tend to reshape social arrangement for distribution and access to resources. "The social structure" is composed of many "semi-autonomous social fields", the definition and boundaries of which are not given by their organisation, but "by a processual characteristic, the fact that it can generate rules and coerce or induce compliance to them" (Moore, 1978). 
It is thus possible to have various laws such as state or statutory law as made by legislature and enforced by the government; religious law including both law based on written doctrines and accepted religious practice and customary law, which may be formal written custom or living interpretations of custom among others (Meinzen-Dick and Pradhan, 2002). Legal pluralism is borne out of these various rules operating in a social setting. It refers to "the coexistence and interaction of multiple legal orders within a social setting or domain of social life" (Meinzen-Dick and Pradhan, 2002: 4).

According to Kameri-Mote (2005), legal pluralism can be divided into; juristic and diffuse. She explained that "Juristic legal pluralism arises in situations where the official legal system recognises several other legal orders and sets out to determine which norms of these legal orders will apply". Under this system, the official legal regime recognises and sets out the operating environment for the existence of plural legal orders. The state law (statutory) is the ultimate authority under the juristic legal pluralism (Kameri-Mote, 2005). Kameri-Mote noted that juristic legal pluralism is common among the colonial and post-colonial Africa of which Ghana is not an exception. Many post-independence governments in West Africa retained the colonial legal systems (Lavigne-Delville, 2000) alongside the indigenous customary law. In the case of Ghana, the colonial legislations before independence largely remained, and where new laws were passed, they were in substance the same as the colonial laws (AUC-ECA-AfDB Consortium, 2011). The land policy and tenure issues in West Africa including Ghana developed within a plural legal environment influenced by different colonial systems (ibid).

Diffuse legal pluralism on the other hand "arises where a group has its own rules regulating social behaviour whose operation is neither sanctioned nor emanates from state law" (Kameri-Mote, 2005:4). This study limits itself to the juristic legal pluralism in the context of state regulations of the customary / local laws on land ownership and transfer. The legal regime of Ghana takes the form of juristic legal pluralism, where colonial laws as well as statutory enactments regulate customary laws of the local communities on many issues including land. Land tenure in Ghana is administered in a plural legal environment (Bugri, 2013; Brako, 2012; Kwapong, 2009). In Ghana, the state exerts enormous control over customary land (Larbi, 2008). The state control over land is exercised through various legislations and constitutional provisions on customary land ownership, administration and transfer system. The co-existence of different legal systems increases the complexities of land rights and security of title and adversely affects access and land use rights of many in Ghana (Brako, 2012). This study benefits from the concept of legal pluralism (juristic) to explore the practical effects of two statutory 
interventions: PNDCL 111 and PNDCL114 on youth land access under the customary land tenure arrangement in the Techiman Traditional Area of Ghana.

There are many legislative interventions in customary land ownership in Ghana operating at different levels (stool/skin and family/household levels). At the stool/skin level, the interventions are largely geared towards ensuring proper and accountable land management and dispositions [see Articles 38, 267 of the 1992 Constitution of Ghana, Administration of Lands Act, 1962 (Act 123) and Office of the Administrator Stool Lands Act, 1994 (Act 481)]. Interventions at the family/household level relate to family landholding and property successions. To appreciate the operational effects of these legislative interventions on youth land access, the study is limited to interventions at the family level where land rights allocation and property succession occur.

\section{The Study Area Profile}

The Techiman Traditional Area is located within the central portion of the Brong Ahafo Region of Ghana (Figure 1). It covers two administrative districts (i.e. Techiman Municipality and Techiman North district) in Techiman traditional area. The area shares traditional and political administrative boundaries with Offinso North district to the south, Nkroranza Municipality and North District to the east, Kintampo South District to the north and Wenchi Municipality in the West.

Agriculture is the mainstay of the economy of the area. The area is generally regarded as an agricultural production corridor. A substantial amount of Ghana's food production takes place within this part of the country (TENDA, 2013). In trying to ascertain how statutory interventions cater for youth access to agricultural land, the area with its prominence in agriculture was thus chosen for this study. 

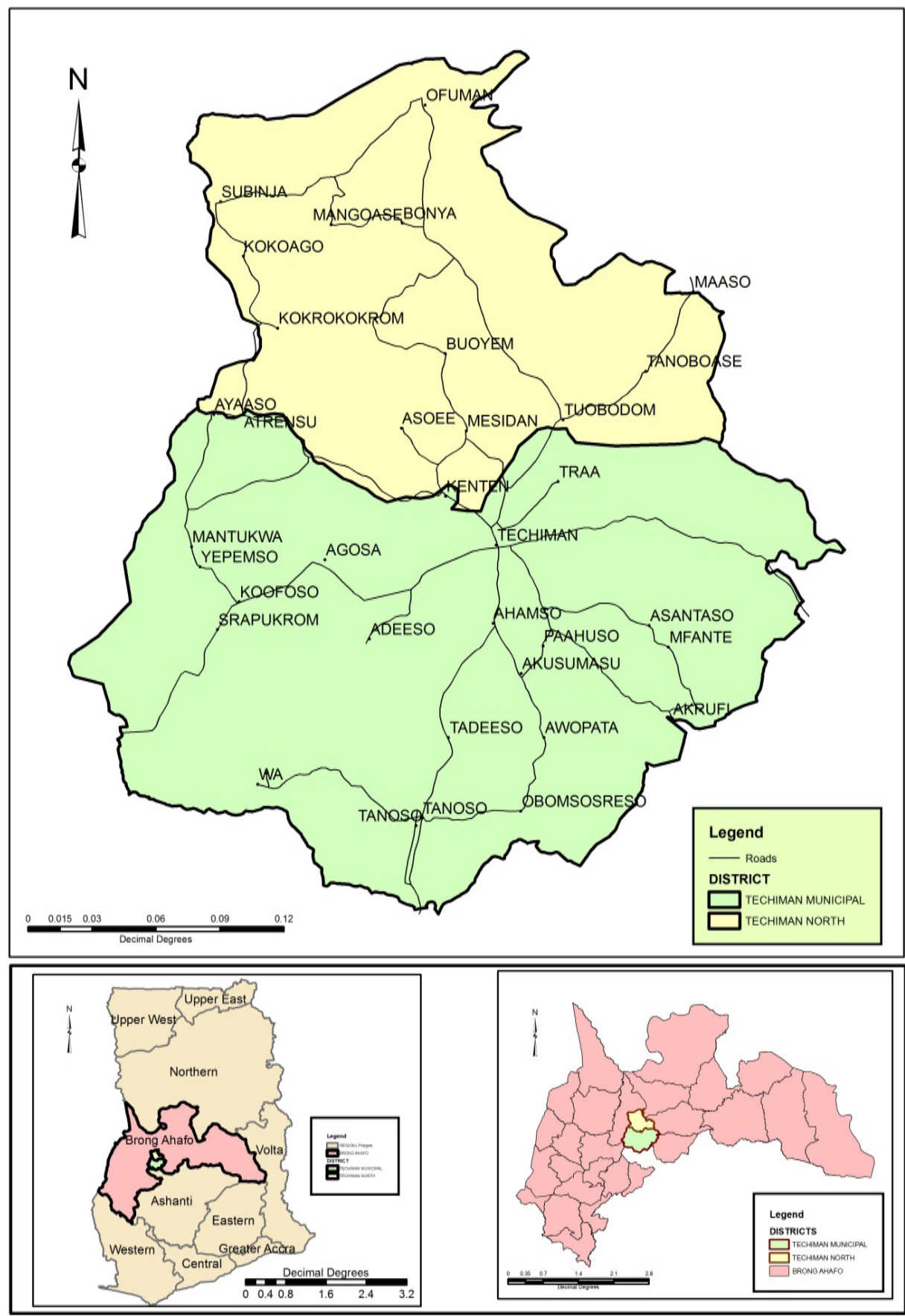

Figure 1: Map of Brong Ahafo Region highlighting the study area

Source: Modified from the Techiman North and South Districts Maps. 
As this study examines the Intestate Succession Law and the youth land access through inheritance, it is important to highlight the inheritance arrangement under the customary system in the study area. In the Techiman Traditional Area, majority of the people are the native Bono-speaking Akan (TENDA, 2013). The inheritance system among the Akan is matrilineal in nature. Per Akan customs children trace their family lineage to their mother's natal home and not that of their father (Hill, 1970; Aidoo, 1996). So a child and the mother belong to one family and the father also belongs to the family of his mother. With respect to property succession, children (nephews and nieces) inherit from their maternal uncles and a child cannot customarily inherit land belonging to his father. Inheritance of land is patterned along this customary conception of a family.

The state through constitutional and legislative provisions has made interventions in the inheritance practices in Ghana. The state under the 1992 Constitution of Ghana, undertakes to 'guarantee the ownership of property and right of inheritance' (Article 36: 7). The enactment of Intestate Succession Law, 1985 (PNDCL, 111) sought to streamline inheritance arrangement in the country and correct discrimination which existed against the surviving spouse and children under the customary inheritance system, especially in the matrilineal system. For instance, the memorandum of the law notes: "At customary law, there is very little protection for a surviving spouse. Neither spouse has a right to the property of the other. Children in a matrilineal system have no more than a right to maintenance by their father's customary successor and a right to residence in their father's house subject to good behavior." Analysis of the effects of this legislative intervention on youth access to agricultural land within the context of the matrilineal system as practised in the study area elucidated above is considered elsewhere in this report.

\section{Methods}

The study covered 20 communities in the Techiman Traditional Area (Table 1). Multiple sampling techniques were employed to select the research respondents. The youth respondents were purposively sampled based on the age criteria of 1534 years and involvement in agricultural activities. Households were used as the reference point in sampling the youth respondents. In order to ascertain how the statutory interventions affected youth land access, it was appropriate to target the youth who had accessed land for agricultural activities. Thus, the study limited the investigation to the youth who operated farms and these were purposively targeted. In all, 455 youth were interviewed using a structured questionnaire. 
Purposive sampling was used to select elders for In-depth Interviews (IDIs). This category of respondents were reputed with special knowledge on landholding and local customs and also vested with authority to administer customary lands. Emphasis was placed on their special knowledge and position in relation to land issues and not necessarily on their numbers. In all, 23 elders were purposively sampled for in-depth interviews.

The IDIs with elders were conducted using an open-ended interview guide. IDIs were recorded using a tape recorder with the exception of few cases which were written in a field notebook as occasioned by exigencies on the field. These recordings were then transcribed and analysed based on the themes under which the interviews were conducted. The transcribed information was studied and summarised. Attention was paid to the areas of consensus and divergence in analysing the transcribed conversations. The analysed data from the transcripts provided the descriptive information that was used to triangulate the information from the youth respondents. Direct quotes from some of the respondents as captured in the transcribed documents are used as necessary. Data from the youth respondents were coded and entered into Statistical Package for Social Sciences (SPSS) software which was then used to generate descriptive statistics used in analysis. This was also used to triangulate qualitative information from the elders interviewed. 
Table1: Number of respondents in the selected communities in the Techiman Area

\begin{tabular}{|l|l|l|}
\hline Community & Youth & IDIs \\
\hline Hansua & 20 & 2 \\
\hline Krobo & 27 & 3 \\
\hline Tuobodom & 89 & - \\
\hline Nkwaeso & 20 & 4 \\
\hline Bamiri & 12 & 1 \\
\hline Twimia-Koase & 21 & 1 \\
\hline Mesidan & 8 & 2 \\
\hline Sansama & 13 & - \\
\hline Kuntunso & 12 & - \\
\hline Aworowa & 39 & 1 \\
\hline Nsuta & 18 & - \\
\hline Buoyem & 14 & 2 \\
\hline Tanoso & 53 & 3 \\
\hline Adieso & 5 & - \\
\hline Tadieso & 11 & - \\
\hline Amangoase & 9 & - \\
\hline Tanoboase & 6 & 2 \\
\hline Offuman & 51 & 2 \\
\hline Kokroko & 5 & - \\
\hline Fiaso & 22 & $\mathbf{2 3}$ \\
\hline Total & $\mathbf{4 5 5}$ & - \\
\hline
\end{tabular}

Source: Field Survey, May 2015

\section{Results and Discussion}

\section{Some Selected Demographic Information of the Youth Respondents}

The study covered a total of 299 male respondents representing $65.7 \%$ and 156 female respondents. Majority of the respondents 186 (40.9\%) fell within the age range (30-34 years) which was the upper limit of the youth respondents. Those in the age category (15-19 years), the lower limit, recorded the least number of respondents of 24 (5.3\%) (Table 2). In terms of the marital status of the respondents, majority 268 (58.9\%) were married while 176 (38.7\%) were single. Only 9 respondents reported they were divorced or separated and 2 respondents were widowed. 
Table 2: Demographic characteristics of the youth respondents

\begin{tabular}{|c|c|c|}
\hline Characteristics & No. of Respondents & Percentage (\%) \\
\hline \multicolumn{3}{|l|}{ Gender } \\
\hline Male & 299 & 65.7 \\
\hline Female & 156 & $34 \cdot 3$ \\
\hline Total & 455 & 100 \\
\hline \multicolumn{3}{|l|}{ Age } \\
\hline $15-19$ years & 24 & $5 \cdot 3$ \\
\hline 20-24 years & 88 & $19 \cdot 3$ \\
\hline $25-29$ years & 157 & 34.5 \\
\hline 30-34 years & 186 & 40.9 \\
\hline Total & 455 & 100 \\
\hline \multicolumn{3}{|l|}{ Marital Status } \\
\hline Married & 268 & 58.9 \\
\hline Single & 176 & 38.7 \\
\hline Divorced/ separated & 9 & 2 \\
\hline Widowed & 2 & 0.4 \\
\hline Total & 455 & 100 \\
\hline \multicolumn{3}{|l|}{ Level of Education } \\
\hline Never been to school & 35 & 7.7 \\
\hline Primary School & 78 & 17.1 \\
\hline Junior High School & 240 & 52.7 \\
\hline Senior High School & 94 & 20.7 \\
\hline Diploma & 7 & 1.5 \\
\hline Degree \& more & 1 & 0.2 \\
\hline Total & 455 & 100 \\
\hline \multicolumn{3}{|l|}{ Primary Occupation } \\
\hline Farmer & 410 & 90.1 \\
\hline Agricultural wage labourer & 4 & 0.9 \\
\hline Non-agricultural wage labourer & 5 & 1.1 \\
\hline Self-employed outside farm work & 23 & 5.1 \\
\hline Student & 7 & 1.5 \\
\hline Public / Civil Servant & 4 & 0.9 \\
\hline Others & 2 & 0.4 \\
\hline Total & 455 & 100 \\
\hline
\end{tabular}

Source: Field Survey, May 2015 
Majority of the youth respondents ended their education at the Junior and Senior School levels. As depicted in Table 2, an overwhelming number of the youth respondents (90.5\%) had low level of education and this situation has implications on their awareness and appreciation of the legislations examined in this study and evidenced in later sections. In terms of occupation of the youth respondents, majority 410 (90.1\%) were involved in farming as their primary occupation. The remaining respondents were only involved in farming as their secondary occupation.

\section{Awareness and Effects of Intestate Succession Law 1985, (PNDCL 111) on the Youth Agricultural Land Inheritance}

In terms of awareness of the Intestate Succession Law, PNDCL 111 among the youth respondents, the results showed that out of the 455 youth interviewed, only $123(27 \%)$ knew about the law while an overwhelming number 332 (73\%) had no knowledge of the law. This knowledge gab among the youth can be linked to many factors including low level of education among the youth respondents, decline in the level of awareness created during the implementation of the law as well as perceived importance of the law among the current generation. Regarding education factor, many of these youth ended their education at the Junior and Senior School levels (Table 2). This perhaps partly explains why most of them do not know about the existence of the law. Formal education, especially beyond the secondary school level, often offers a learning platform in respect of some of the important laws which affect the operation of society.

Essentially, the law was promulgated some three decades ago in response to unfair customary practices against surviving spouse and children in the inheritance of a man's property who dies intestate especially in the matrilineal communities of southern Ghana. As will be shown later, the law since its promulgation has somehow been successful in addressing some of the problems underlying property succession which necessitated its passage. This development has perhaps created a situation where the importance of the law is no longer being emphasised and things now appear to run on their normal course. Consequently, continuous awareness creation to enable the succeeding generations to be acquainted with the existence of the law has been affected partly accounting for the low of level of awareness as seen among the youth respondents in this study.

In order to appreciate the operational effects of the law, it is important to reflect on some relevant provisions under the law under Section 2 which state as follows;

(1) A person shall be deemed to have died intestate under this Law if at the time of his death he had not made a will disposing of his estate. 
(2) Any person who dies leaving a will disposing of part of his estate shall be deemed to have died intestate under this Law in respect of that part of his estate which is not disposed of in the will and accordingly the provisions of this Law shall apply to such part of his estate.

The law does not affect stool or family property under section 1 (2). It is in respect of self-acquired property that PNDCL 111 operates. Under Section 18 on 'Interpretations' "estate" means "self-acquired property which the intestate was legally competent to dispose of during his lifetime and in respect of which his interest has not been terminated by or on his death".

This intervention in the inheritance arrangement according to the elders interviewed has changed inheritance arrangement especially in the matrilineal system in the distribution of undisposed estates of a deceased person. Under section 4 of the law, it prescribes that;

Notwithstanding the provisions of this Law:-

(a) where the estate includes only one house the surviving spouse or child or both of them, as the case may be, shall be entitled to that house and where it devolves to both spouse and child, they shall hold it as tenants-in-common;

(b) where the estate includes more than one house, the surviving spouse or child or both of them, as the case may be, shall determine which of those houses shall devolve to such spouse or child or both of them and where it devolves to both spouse and child they shall hold such house as tenants-in-common:

These provisions now make it possible for surviving spouse and children to benefit from either their deceased father or mother. Under the matrilineal inheritance arrangement, children are not part of the distribution list of the estates of their deceased father. The elders interviewed believed that, these provisions in the law have altered the customary arrangement which now favours the children and the surviving spouse. These elders shared their understanding on the current operation of the law in terms of its benefits in the following;

I am aware of the PNDCL 111. It has helped a lot of young people to inherit from their fathers. In the past, a person will toil and make investments and when he dies, the family will say they have taken over all the property. These days, such customs are resisted under the law. (Elder, 68-year old, IDI, Tanoso, 2015).

Another concurs;

The PNDCL 111 has now changed the inheritance situation. Personal properties of a person now belong to his children and the spouse. If the 
person does not make a will, and leaves behind a house, the children and the spouse will normally take all. (78-year old Family head, IDS, Buoyem, 2015).

PNDCL 111 has had some positive effects on the inheritance rights of young people in the Akan matrilineal inheritance area of Techiman as opined by the elders interviewed. As noted from the narrations of these elders, houses and household chattels are normally inherited by surviving spouse and children. Despite this modest success of the law in the inheritance of personal properties like houses and chattels, the case is different when it comes to inheritance of agricultural land of families. Farm lands in these settings are generally treated as family property which is outside the purview of PNDCL 111. A typical view expressed by the elders interviewed was that, farm lands were family property which cannot be inherited under the Intestate Succession. This view was echoed by a 78-year old elder at Krobo as follows:

Properties like cars or houses are inherited under the PNDCL 111 without contestations. As for farm land, the law does not apply to its inheritance. Farm land is a family property; even the state knows that. Even if the deceased person left behind a cocoa farm, it could be that the person also inherited the land from somebody in the family to do that investment (Elder 78 years old, IDI, Krobo, 2015).

Another agrees,

I don't think intestate law even applies to land (referring to farm land). Children are born into a family, and they cannot come and tell the family that, they want to use intestate law to share their father's land which may even form part of the deceased family land stock (Elder, 73-year old, IDI, Nkwaeso, 2015).

The law as indicated earlier applies to personal property and the elders interviewed largely affirmed this position. The elders understood the law to be in respect of chattels and houses as noted from their narrations. Yet, if as noted by the 78 year old elder of Krobo that cocoa farm of a deceased could not even be inherited by the children and spouse because the investment is on family land, then difficulties arise in the distinction between the personal resources invested in the cocoa farm (self-acquired) and the land for the cocoa farm (family property). Some of the youth respondents however also affirmed the position of their elders. The youth noted that, their elders often argue that, farm lands were appropriated by their ancestors in the past long before the PNDCL 111 was promulgated and so the law does not apply to farm lands. A typical response by the youth was as that; 
There are problems inheriting agricultural land under PNDCL 111. Elders always say that farm lands were appropriated by our ancestors before the PNDCL 111, so the law does not apply to land. Even if your mother inherited the land and has died; the children cannot claim ownership of the land under PNDCL 111 (Takyi, 32-year old youth, Interview, Twimia, 2015).

It is important to note that both the framing of PNDCL 111 in its exemption of application to family land and the nature of agricultural landholding pose operational difficulties for the law in the study area. Agricultural lands according to the elders interviewed, were largely appropriated in the past by the ancestors of the various families many of whom left behind those lands undisposed. These lands became family property where individual members continue to occupy with some making long term investment like cocoa or cashew. Members of the family continue to recognise these lands as family property even though individuals may have inherited portions from other members who earlier used those lands. One elder opined in the following;

Agricultural lands are largely family land and the person currently holding it will have to be succeeded upon death. Our ancestors acquired these lands through their personal effort and many died leaving the land undisposed. Those self-acquired lands, which were not disposed of before the owners' demise, became family property and passed onto the next generations under the inheritance system. These lands will continue to remain family property so long as the family exists (Elder, 76-year old, IDI, Buoyem, 2015).

Thus, an attempt to take over a portion of those lands under the PNDCL 111 is resisted by the family elders who view the move as an attempt to reduce family property into a personal property. This move also breaches the PNDCL 111 itself which does not affect family property (See Section 1 [2] of PNDCL 111). As confirmed by the elders during interviews, for houses and household chattels, the children and surviving spouse are entitled to inherit without the family contesting for a portion especially if it is one house. Properties such as houses and chattels acquired by a person are treated as personal property. However, when it comes to agricultural land, it is regarded as family property. The only exception is where the deceased bought land without the support or resources of the family. These situations are few as rights to use agricultural land emanate largely from the family land holdings. The rights created over family land for agricultural use are expected to be disposed of in line with customary arrangements. The youth are thus not able 
to benefit from the operation of the PNDCL 111 in accessing family agricultural land through inheritance arrangement.

The customary process is very well entrenched and the elders maintained that agricultural lands are family property acquired in the past by their ancestors long before the coming into being of PNDCL 111. Once a family land, always a family land; as such the right to own a portion of the land must be gained through the custom. Consequently, the current customary arrangements governing succession to family land are difficult to circumvent and PNDCL 111 as it exists now has no provision to reduce the family property into individual property upon the death of any family member who possessed a portion of family land.

In terms of the practical application of the law on the youth's inheritance rights to agricultural land, only 20 (4.4\%) out of the 455 respondents inherited land and none of the 20 heirs did so under the PNDCL 111. This affirms the widespread nature of family land in the Techiman area which cannot be inherited under the law. It is instructive to note that, 14 of the inheritances occurred under the customary matrilineal inheritance arrangement while the remaining 6 inheritances were through statutory 'will' prepared by their successors who had capacity to dispose of those lands through 'will'. Females were more likely to inherit land than their male counterparts. Among the female respondents, 10 (7\%) out of the 156, inherited land while 10 (3\%) out of the 299 male youth respondents also inherited land. Though the percentage of inheritance was low among both female and male respondents, generally the customary matrilineal inheritance system favours the female than the male as revealed by this result. Females are considered part of the family of their mother and so can inherit their mother's properties but the male cannot directly inherit properties of their mothers. Inheriting from one's mother as a male would mean taking the property out of the mother's family. This youth respondent shared this view in the following words:

In this area, we the boys do not have control over land. Even with your mother's land, it is our sisters who control the land. They say as a male if you marry your children belong to another family. So when we are given land, it will go out of the family (Sarkodie, 29-year old male youth, Tuobodom, 2015).

The above findings reveal that, had PNDCL 111 come earlier than 1985 and had it been made applicable to family land, it could have facilitated land transfer from parents to children and ensured farm investments remained within one's nuclear family. It however did not only come late, but is currently not applicable to family land. Thus, Benneh et al. (1995) observed that, all lands are either stool or family 
lands and have already been accumulated through the various matrilineal lineages in Akan areas. Therefore, the youth are unable to access family land through inheritance under the PNDCL 111 or take over farm investments of their deceased parents who made such investments on family land. The customary process still governs succession to agricultural land in the Techiman area with the female dominating in terms of access and ownership through inheritance under the customary process due to the prevailing matrilineal inheritance practices. Benneh et al. (1995) similarly noted in the case of peri-urban areas of Kumasi that, most lands under the matrilineal inheritance system were reduced to family lands and largely controlled by women. The findings of this study corroborate the observation by Benneh et al. (1995).

\section{Head of Family Accountability Law, 1985 (PNDCL 114) and the Youth Land Rights}

The state under article 18 of the 1992 Constitution of the Republic of Ghana, grants every citizen the right to own property whether as an individual or in association with others. Thus, the right of families to own property to the benefit of all members is recognised by the state and the state further enjoins managers to be accountable to the beneficiary members. Under Chapter Six of the Constitution on Directive Principles of State Policy, "The State shall recognise that ownership and possession of land carry a social obligation to serve the larger community and, in particular, the State shall recognise that the managers of public, stool, skin and family lands are fiduciaries charged with the obligation to discharge their functions for the benefit respectively of the people of Ghana, of the stool, skin, or family concerned and are accountable as fiduciaries in this regard" (Article. 36:8). The Head of Family Accountability Law essentially seeks to operationalise this constitutional directive especially in the case of family lands and other family properties, albeit this law existed before the promulgation of the constitution. This legislation makes a direct intervention in family property holding and seeks to ensure accountability in the management of family property in the Ghanaian society.

It is imperative to examine the extent to which this legislative intervention helps the youth in their access to agricultural land or benefit from proceeds from the disposition of family lands of which they have a beneficial interest as members of the family. It is useful to first note the relevant provisions of the law.

\section{Section 1}

(1) Despite a law to the contrary, a head of family or a person who is in possession or control of, or has custody of, a family property is accountable for that property to the family to which the property belongs. 
(2) A head of family or a person who is in possession or control of, or has custody of, a family property shall take and file an inventory of the family property.

\section{Section 2}

(1) Where a head of family fails or refuses to render account or file an inventory of the family property, a member of the family to which that property belongs who has or claims to have a beneficial interest in the property, may apply by motion to a Court for an order compelling the head of family to render account or file an inventory of the family property to the family.

These provisions enjoin family head or any member of the family who is in possession or control of family property to account to the rest of the family. Failure on the part of the family head to account could cause any family member whether young or old who has a beneficial interest in the property to 'apply by motion to a Court for an order compelling the head of family to render account or file an inventory of the family property to the family'. According to Kludzi (1987:114) "Each member of the family holds an undivided and unspecifiable share in every family property". This confers on every family member a beneficial interest in the family property. The right to institute action against the family head to account is thus conferred on every member regardless of sex, age or status in the family. But this right of any family member to seek an order to compel the family head to account "shall not be entertained by the Court unless the Court is satisfied that the applicant had taken steps to settle the matter within the family and that the attempts had failed" (see Section 2 (2). The law gives consideration to settlement of accountability issues at the family level at the first instance before anybody can run to the cover of this law.

\section{Awareness and Application of the Law}

The youth as members of the social structure have beneficial interest in their families' property and can invoke the provisions of this law to demand that their family heads account for the property (both moveable such as money and immovable such as farm lands or houses) in their possession. This study sought to find out whether the youth were aware of the law and had ever invoked the provisions of the law against their family heads or any member of their family who is in possession of the family property. Out of the 455 youth respondents, only a small number, $58(12.7 \%)$ indicated they knew there is a law called the Head of Family Accountability which requires family heads to account for the family property in their possession. An overwhelming number, 397 (87.3\%) of the youth did not know about the law. Of the 58 youth who knew about the law, 
only 5 said they had witnessed occasions where some families had dragged family heads to court over accountability issues relating to family property. According to these respondents, they had not personally invoked the provisions of the law to compel their family heads to account. The rest of the youth respondents had not acted under the law and had also not witnessed any family property issues being addressed under the law.

The high level of lack of knowledge among the youth regarding the Head of Family Accountability Law is partly attributable to the low level of formal education among the youth respondents in the study area. Formal education which could have offered the youth the platform to learn about this legislation was low among them as reported earlier. Again, sensitisation programmes aimed at educating the public including the youth to appreciate some of the laws which regulate social interactions and protect the rights of people have been generally lacking in the country.

Interview with the elders also revealed a similar lack of knowledge about the existence of the statutory law which requires them to be accountable to their families. They knew of accountability as required by custom and not under statutory legislation. Some of these elders shared their knowledge in the following:

I don't know about the law (referring to Head of Family Accountability Law). In our traditional system, as a family head you have to account to the family, because the property is not your personal property. But there are some family heads who will not make effort to render account. They allocate land to outsiders and take money. They will buy cloth for funerals without thinking about their youth (Sub-Chief, IDI, Tanoso, 2015).

Another added;

It is a customary requirement to account, I don't know of a law made by government which requires that family heads account for land or property in their possession. (Elder, 65-year old, IDI, Bamire, 2015).

The elders interviewed considered accountability as a customary requirement and not much of a statutory requirement. Family heads are by custom accountable to families in respect of family property in their possession. According to Kludze (1987), customary law already insists on accountability from the family head. This position is statutorily affirmed by PNDCL 114. The law recognises customary accountability and even requires that aggrieved family members first try to 
resolve accountability issues at the family level before proceeding to the court or instituting any action under the law.

However, the customary accountability process at the family level as encouraged by the law is beset with some practical difficulties. Per the rule of customary law, the family head is the proper person to have custody and possession of family property (Sarbah, 1904; Ollennu, 1985). According to Sarbah, a family head under the customary law is not accountable to the junior members of the family and that no member of the family can insist on being allocated a portion of family property (Sarbah, 1904 cf; Kludze, 1987: 115). This very much disables the youth in seeking accountability under the customary arrangement as encouraged by the PNDCL 114 as a first step in the accountability process. It should however be pointed out that, modernity and civilisation are gradually eroding the customary law position that family heads are not accountable to their youth in relation to family or stool properties in their possession. Though this development was not observed in the Techiman area, there is a known case in Adomfe community in the Asante Akyem South District of Ashanti Region, where the youth of the community took their chief to court over proceeds from the community's water ${ }^{20}$.

Moreover, the customary law also confers on the family head wide discretionary powers in the disposal and management of family property (Kludze, 1987). This was the case in the disbursement of proceeds earned from the conversion of agricultural land to residential lands in the peri-urban communities in the Techiman area. Family heads were the recipients of the portion of land or proceeds allocated to the family by the town chiefs in the conversion of agricultural land to other uses. The family head after receiving the portion allocated to the family uses his discretion to decide whether younger family members should benefit or not. An elder noted;

For the plots allocated to the family, it is the family head who will decide that may be this person or young person in the family has worked so hard on the land, so I will give him/her something. (Elder, 78-year old, IDI, Krobo, 2015).

This discretionary power of the family heads in sharing land proceeds tends to undermine social justice and fairness. For instance, some of the youth respondents interviewed in the peri-urban areas indicated they had been denied share of

20 See Addai Nketiah (Suing for and on behalf of the youth of Adomfe Ashanti) Vrs Water and Sanitation Committee of Adomfe and Nana Adomfe Adjei II, Chief of Adomfe, (2014), Suite no. C12/205/14, Kumasi High Court. The case related to the sale of water which was believed to have spiritual and healing powers. Many people trooped to buy the water and this brought in a lot of money which the chief hijacked. 
proceeds from the family lands they occupied which were converted into residential use. This youth respondent shared his experience;

My father left about 10 acres of land on which I cultivated 6 acres. The chief demarcated the land into residential plots. The family head received a number of plots as the share of the family, but he sold everything without giving me anything (Interview, Jacob, 32-year old youth, Twimia, 2015).

No family head was summoned before the family council or the court to account for the use of those proceeds by the youth. The youth respondents even expressed fear in trying to ask their family heads to account. This youth respondent remarked; "I don't want to challenge these elders and get into their trouble. You can even die" (Fosuaa, 26-year youth, Interview, Kuntunso, 2015). Though as part owners of family property the youth have right to demand accountability from their family heads over the use of family lands, it is often in reality a daunting task for them. The tradition of respect for the elders especially the family head is still revered. Any young family member who will attempt to call the family head to account will be viewed as rude and disrespectful not to even mention of seeking a judicial accountability under PNDCL 114.

It is argued that, requiring a family head to prepare and render accounts as required by PNDCL 114 is in essence questioning his discretionary powers in the use of family property under the customary arrangement. Thus, no member of a family including the youth would want to risk in demanding accountability from their family heads over the handling of family land. As noted by Benneh et al. (1995: 33), it is "Only a "trouble shooter" would risk calling a family meeting for the sake of accountability, especially if the caller has contributed nothing to the accumulation of the family property'. The youth's contribution to accumulation of family/household property (land) is negligible. At the family and household level, the heads largely expend their resources and energy in the acquisition of land or are customarily vested with power to handle land inherited from their ancestors. The locus granted to all members of the family including the youth under PNDCL 114 to demand accountability over holding of family property is deficient in this circumstance. It should however be equally noted that, some of the family elders' contributions to the accumulation of family property which then entitle them to unfettered control over family land as opined by Benneh et al. are equally negligible. Many of these family lands were acquired in the past by the ancestors and the elders are only privileged to be vested with authority over those lands. This calls for fair play between the elders and their youth in the use and enjoyment of resources bequeathed to them by their ancestors. 


\section{Conclusions and Recommendations}

Legislative interventions examined in this study which relate to property succession and landholding accountability at the family level in Ghana have had mixed outcomes for the youth in the Techiman area. In the case of Intestate Succession Law, it has been useful in the inheritance of personal properties such as chattels and houses as revealed by the findings from the Techiman area. It now makes it possible for children to be able to inherit their deceased parents' personal properties in the matrilineal system which used not to be the case in the past when the law was not yet promulgated. However, its non-applicability to family lands has impeded youth access to family lands for agricultural purpose through inheritance under the law. The law in its current state does not facilitate inheritance rights of the youth to agricultural land. Agricultural lands are largely regarded as family property created by family ancestors long before the promulgation of the law. Access to these lands through inheritance is therefore outside the domain of the PNDCL 111. The right to use or own any portion of family land is expected to be acquired in line with the customary arrangement and this disables the youth's ability to access such lands through inheritance under the PNDCL 111. Yet, there is some justification in an extension of the law to family land that deceased family members expended private resources to develop. This will make it possible for children of a deceased family member who have invested private resources to develop a family land into such as cash crop plantation to inherit at least a portion of the investment.

The Head of Family Accountability Law, 1985 (PNDCL 114) has not helped the youth in asserting claims to land and also seeking accountability over land proceeds from their family heads. Cultural factors such as respect for the elderly and wide discretionary powers of family heads over the use and management of family property coupled with inherent weaknesses of the law have together undermined the youth's pursuit for land rights under the law. This study found that no youth respondent had ever directly taken an action under the law. The level of awareness of the law among the youth and even among their elders was very low further compounding the already defective nature of the law.

It is recommended that these legislations be reviewed to make them useful to the contemporary Ghanaian society. Already, the Intestate Succession law is under review and an Intestate Succession Bill is currently before parliament of Ghana. The Bill should make relevant provisions on inheritance of family land to enable the youth access and benefit from their immediate parents' investment on their family lands. Extending the law to the inheritance of family property will also widen the land access scope of the youth through inheritance, as family lands are the 
dominant landholding arrangement under the customary system in Ghana. The Bill should require that, a portion of investment made on family land with personal resources by a family member who dies intestate be given to his/her surviving children. Life interest could then be created in respect of the portion so devolved onto the surviving children.

The Head of Family Accountability law also needs review and in this regard, Alternative Dispute Resolution (ADR) mechanisms should be made an integral part of the law since court actions to demand accountability have not generally been culturally acceptable. The youth tend to be reluctant to drag their family heads to court over proceeds from family property. The awareness level of these two important statutory interventions is also low and efforts should be made by the relevant stakeholders such as district assemblies, civil society organisations and NGOs to sensitise the public on the existence of these laws so that they can be used to assert their land rights claims and benefits.

\section{References}

Abbink, J. (2005). Being young in Africa: The politics of despair and renewal (ed. Abbink, J., and Ineke van Kessel), In:Vanguard or vandals: youth, politics and conflict in Africa, Brill, Leiden; Boston.

Agbosu, L.K. (2000). Land law in Ghana: Contradiction between Anglo-American and customary conceptions of tenure and practices, Working paper No. 33, Land Tenure Center, University of Wisconsin-Madison.

Aidoo, J. B. (1995). Tenancy and the Land Reform Debate in Ghana, In: Land Tenure and Land Management Series, Our Common Estate, Royal Institution of Chartered Surveyors, London.

Asiama, S.O. (2008). Land Administration and Security of Tenure in Ghana - The Legal Framework, Journal of Ghana Institution of Surveyors, Vol. 1, No.1, pp. 76-84.

Arko-Adjei, A. (2006). A Conceptual Approach for Enhancing Customary Land Management: Case from Ghana. 5th FIG Regional Conference Accra, Ghana, Eilat, Israel, March 8-11, 2006. pp. 1-18.

Annan, K. (2013). “Let the young lead”. A speech delivered on the occasion of World Youth Day, August 12, Accra. Available at: http://edition.radioxyzonline.com/ pages/news/o8122013-1625/13880.stm Accessed on August 13, 2013.

AUC-ECA-AfDB Consortium (2011). Land Policy in Africa: West Africa Regional Assessment. Available at: http://www.uneca.org/sites/default/files/ 
publications/regionalassesment_westafrica.pdf , Accessed on August 30, 2014 .

Benneh, G., Kasanga, R.K. and Amoyaw, D. (1995). Women's access to agricultural land in the household: A case study of three selected districts in Ghana. Fadep Technical Series, No. 8, University of Ghana.

Berry, S. (2009a). Property, authority and citizenship: Land claims, politics and the dynamics of social division in West Africa. Development and Change Vol. 40, No. 1: pp. 23-45, Institute of Social Studies.

Berry, S. (2009b). Building for the future? Investment, land feform and the contingencies of ownership in contemporary Ghana. World Development Vol. 37, No. 8, pp. 1370-1378.

Boni, S. (2008). Traditional ambiguities and authoritarian interpretations in Sefwi land disputes, In: Contesting land and custom in Ghana, State, Chief and the Citizen, Edited by Ubink J. and Amanor.K. S., Leiden University Press, Amsterdam

Boni, S. (2006) 'Indigenous Blood and Foreign Labor: The Ancestralisation of Land Rights in Sefwi (Ghana)', in R. Kuba and C. Lentz (eds) Land and the Politics of Belonging in WestAfrica, pp. 161-86. Leiden: E.J. Brill.

Brako, C.A. (2012). The estate surveyor's role as a facilitator in land conflict resolution, A paper presented at the 2012 Annual Seminar of the Valuation and Estate Surveying Division of Ghana Institution of Surveyors at GIMPA Executive Conference Hall, Accra, 27-28th September, 2012.

Brooks, K., Zorya, S., Gautam, A. and Goyal, A. (2013). Agriculture as a sector of opportunity for young people in Africa. Policy Research Working Paper 6473. Agriculture and Environmental Services Department, the World Bank.

Bugri, J. T. (2013). Issues and Options for Improved Land Sector Governance in Ghana: Application of the Land Governance Assessment Framework (LGAF). The Ghana Surveyor, Vol. 1, No. 1, pp. 21-35.

Cotula L. (2007). Changes in "customary" land tenure systems in Africa ISBN: 978-184369-657-5, London: IIED.

Deininger, K., (2003). Land policies for growth and poverty reduction, Washington DC, World Bank.

Dupret, B. (n.d). Legal pluralism, plurality of lws, and legal practices: Theories, critiques, and praxiological re-specification.

FAO, (2002). Gender and access to land, Food and Agriculture Organisation (FAO) Land Tenure Studies No. 4, Rome, Italy. 
Fisher, R. (1993). Tensions and tenures in post-apartheid South Africa. December 1993International Land Tenure Conference. Royal Institute of Chartered Surveyors and the University of East London.

Gadalla, S.M. (1970). Land reform in relation to social development in Egypt. University of Missouri Studies, Vol. XXIX, Unp. Columbia.

Gildea Jr., R.Y. (1964). Culture and land tenure in Ghana. Land Economics, Vol. 40, No. 1, pp. 102-104.

GoG, (1999). National land policy, Government of Ghana (GoG). Accra: Ministry of Lands \& Forestry.

GoG (1992). The Constitution of the Republic of Ghana, 1992.

GSS (2012), 2010 population and housing census, summary report of final results. Ghana, Accra: Ghana Statistical Service.

Griffiths, J. (1986). “What is legal pluralism?” Journal of Legal Pluralism, No. 24, pp. 1-55.

IFAD (2010). 'Rural pverty report 2011'. Rome: International Fund for Agricultureal Development.

Hill, P. (1970). The Migrant Cocoa-Farmers of Southern Ghana, A study in rural capitalism, 2nd Edition, Cambridge University Press.

Kasanga, R.K, (1988). Land tenure and the development dialogue: The myth concerning communal landholding in Ghana, Occasional Paper 19, Department of Land Economy, University of Cambridge, Granta Editions Ltd.

Kameri-Mbote, P. (2005). The land has its owners!; Gender issues in law tenure under Kenya Customary Law, International Environmental Law Research Centre Working Paper, 2005-9,http://www.ielrc.org/content/w0509.pdf , Accessed, August 28, 2012.

Kidido, J.K, Bugri, J.T and Kasanga, R.K. (2017). Dynamics of youth access to agricultural land under the customary tenure regime in the Techiman traditional area of Ghana. Journal of Land Use Policy, Vol. 6o, pp. 254-266.

Kwapong, O. (2009). The Poor and land: A Situational analysis of access to land by poor land users in Ghana, Journal of Rural and Community Development, Vol. 4, pp. 51-66.

Kludze, A.K.P. (1987). Accountability of the head of family in Ghana: A statutory solution in search of a problem. Journal of African Law, Vol. 31, No. 1/2, pp. 107-118. 
Larbi, W.O. (2008). Compulsory land acquisition and compensation in Ghana: Searching for alternative policies and strategies, FIG/FAO/CNG International Seminar on State and Public Sector Land Management, Verona, Italy, September 9-10, 2008.

Lavigne-Delville, P.A. (2000). Harmonising formal law and customary land rights in French speaking West Africa. In Toulmin, C. and J.F. Quan (eds.), Evolving land rights, policy and tenure in Africa. London, Department for International Development/International Institute for Environment and Development / Natural Resources Institute.

Lintelo, D. (2011). Youth and policy processes, Future Agricultures, Working Paper 025 .

Moore, S.F. (1973). Law and Social Change: The semi-autonomous field as an appropriate field of study. Law and Society Review 70: 719-746.

Moore, S.F. (1978). Law as process: An anthropological approach, London, Henley and Boston, Routledge \& Kegan Paul.

Mends, T (2006). A study on the customary land tenure system and its impact on urbanisation. Case study: The peri-urban area of Accra, Ghana. MSc. Thesis ITC Netherlands.

Meinzen-Dick, R.S. and Pradhan, R. (2002). Legal pluralism and property rights,CAPRi WORKING PAPER NO. 22, International Food Policy Research Institute (IFPRI).

Mifsuf, F.M. (1967). 'Some legal aspects of African Land Reform' In: land taxation, land tenure and land reform in developing countries, University of Hartford, Connecticut.

MYS, (2010). National youth policy of Ghana, Accra: Ministry of Youth and Sports (MYS).

Ollennu, N.A. (1985). Principles of customary land waw in Ghana, 2nd Edition, Sweet and Maxwell, London.

Ollennu, N. A. (1962). Principles of Customary Land Law in Ghana, Sweet and Maxwell, London.

Sarbah, J.M. (1904). Fanti customary laws (2rd ed.) Cass, London.

Sharp, L.A. (2002). The sacrificed generation. Youth, history and the colonised mind in Madagascar, Berkeley, Los Angeles \& London: University of California Press.

TENDA, (2013). Profile of Techiman North District Assembly, Tuobodom. 
White, B. (2011). Who will own the countryside? Dispossession, rural youth and the future of farming, Valedictory Lecture on 13 October on the occasion of the 59 th Dies Natalis of International Institute of Social Studies (ISS), The Hague.

World Bank, (2007). Development and the next generation: World Development Report 2007. Washington DC: The World Bank.

Woodman, G.R. (n.d). Customary law in common law systems, University of Birmingham, UK.

Woodman, G.R. (1998). 'Ideological combat and social observation: Recent debate about legal pluralism', Journal of Legal Pluralism, No.42, pp 21-59.

World Bank (2010). Land governance assessment framework: Implementation manual for assessing governance in the land sector. Washington DC20433: The World Bank.

World Bank (2014). Youth employment in Sub-Saharan Africa, Africa Development Forum, Washington DC: The World Bank. 